\title{
Relationship between Ownership Structures and Earnings Management Behavior in Vietnamese Commercial Banks
}

\author{
Thinh Quoc TRAN ${ }^{1}$, Anh Hoang LY², Dung Khanh Ngoc NGUYEN ${ }^{3}$ \\ Received: July 03, 2020 Revised: July 19, 2020 Accepted: August 10, 2020
}

\begin{abstract}
Earnings management behavior is the use of accounting procedures, through accounting policies, to intentionally purposeful control in the provision of information to users. The purpose of this paper is to examine the relationship between ownership structure factors and earnings management behavior of 30 Vietnamese commercial banks. The paper uses the ordinary least square method to examine this relationship and employs time series data of 15 years from 2005 to 2019. The study also uses agency theory an asymmetric information theory. The authors examined six independent variables related to the ownership structure and these variables are typical of Vietnamese commercial banks. The results of the study show that the foreign ownership ratio is an opposite effect, while the ownership concentration variable has a positive effect on earnings management behavior of Vietnamese commercial banks. Based on that, the article proposes a number of policy suggestions for the State bank of Vietnam and Board of directors of commercial banks as well as investors to identify and to limit the earnings management behaviors of Vietnamese commercial banks. This contributes to ensuring information transparency as well as improving the quality of accounting information of Vietnamese commercial banks in the coming years.
\end{abstract}

Keywords: Accounting Information, Behavior, Commercial Banks, Earnings Management, Ownership Structure, Vietnam

JEL Classification Code: M41, D22

\section{Introduction}

Earnings management behavior (EMB) is the deliberate intervention of providing information to users in order to achieve managers' own goals. EMB affects the quality of information in the financial statements of the entity (Schipper, 1989). Research shows that there are many motivations for EMB such as salary and bonuses for managers, so when the opportunity exists, managers will implement EMB to adjust earnings (Ali, Salleh, \& Hassan, 2008; Shaikh, Iqbal, \& Shah, 2012; Alves, 2012).

${ }^{1}$ First Author and Corresponding Author. Associate Professor, Faculty of Accounting and Auditing, Industrial University of Ho Chi Minh City, Vietnam [Postal address: 86 Nguyen Hong, Ward 1, Go Vap District, Ho Chi Minh City, 70000, Vietnam] Email: tqthinhkt@gmail.com

${ }^{2}$ Associate Professor, Faculty of Business Administration, Saigon University, Vietnam. Email: pgslyhanganh@gmail.com

${ }^{3}$ Lecturer, Faculty of Accounting and Auditing, Industrial University, Vietnam. Email: tsnguyengnockhandung@gmail.com

(c) Copyright: The Author(s)

This is an Open Access article distributed under the terms of the Creative Commons Attribution Non-Commercial License (https://creativecommons.org/licenses/by-nc/4.0/) which permits unrestricted non-commercial use, distribution, and reproduction in any medium, provided the original work is properly cited.
EMB is the focus of interest of many studies and mostly on businesses, while research into the banking sector is quite modest. The studies have acknowledged many factors affecting the quality management of commercial banks related to variables of corporate governance or financial indicators on the financial statements (Tran and Tran, 2020), among which the factors of ownership structure has a significant influence on the EMB (Tran and Nguyen, 2018; Osemene, Adeyele and Adinnu, 2018; Sadjiarto, Monica and Budiarti, 2019). Ownership structure associates interests among stakeholders, including the Board of directors and CEO. This is reflected in the financial policies related to dividends, share bonuses, or buying shares at preferential prices (Shen, 2016). Factors related to basic ownership structure include variables such as managerial ownership, foreign ownership, state ownership, institutional ownership, ownership ratio of the Board members, and the concentration of ownership rights. These are the variables that significantly influence EMB in commercial banks because of the direct benefit to the managers.

In Vietnam, considering the relationship between ownership structure and EMB, there have been a few studies of companies listed on Vietnam's stock market, but in-depth 
research in the field of banking is limited (Tran and Nguyen, 2018). This is an issue that has always received attention from information users in order to have a basis for identifying EMB, thereby contributing to improving the quality of accounting information of Vietnamese commercial banks, which is weak. It is important to ensure users' confidence in the strength of the country's banking system and financial markets.

\section{Literature Review}

\subsection{Related Concepts}

Jensen and Meckling (1976) saw the ownership structure as the capital held by members of the company compared to outside investors and suggested that if the company had large shareholders, it would increase the performance and company values. Potta, De-Silanesn and Shleifer (1999) based on agency theory according to which, when a company is owned by large shareholders, there is a phenomenon that these shareholders seek to bring their own benefits, so the efficiency is often inferior. Accordingly, the ownership structure can be interpreted as the percentage of equity held by the owners. Ownership structures often influence managers' decision-making. Ownership structure is seen by the degree of ownership concentration and stock ownership.

There is no consensus on what the terms of reference are on EMB. Schipper (1989) argues that the EMB is the adjustment of a manager's earnings to achieve the desired goal, or that the managerial intervention in providing financial information related to corporate accounting policies (Beneish, 2001; Healy and Whalen 1999). Akers, Giacomino, and Bellova (2007) recognize that EMB is an attempt by managers to adjust information about financial statements through related accounting policies. It is the use of techniques related to accounting data to be able to adjust information within the limits related to the financial statements in order to gain private benefits. Managers who engage in EMB practices may contribute to improving the potential and value of the entity, but affect the quality of information (Tangjitprom, 2013). Accounting policies and methods are implemented in accordance with general standards and principles, EMB is to comply with the regulations, but skillfully apply policies to present the financial statements in a favorable way by managers (Rahman, Moniruzzaman and Sharif, 2013).

\subsection{Theoretical Perspectives}

\subsubsection{Agency Theory}

Jensen and Meckling (1976) are the pioneers in the formation of Agency theory. This theory refers to the relationship between the authorizing party and the mandated party. In this relationship, conflicts of interest can form. Different from the owners' expectations, managers expect to gain their own benefits through behaviors that affect the interests of shareholders. Therefore, in order to reduce conflicts of interest between the mandate and the mandate, monitoring mechanisms should be set up to limit managerial self-interest. The Agency theory is often used in this study to verify the influence of factors related to the ratio of ownership of executive managers, ownership of members of the Board of directors and the degree of centralized ownership because these are issues that affect benefits between the authorizing party and the authorized party or in other words, between the Board of directors and the Board of directors.

\subsubsection{Asymmetry Information Theory}

This theory was first mentioned by Akerlof (1970) and then added by Spence (1973). Asymmetric information occurs when one party has less or insufficient information compared to the other party. This will cause the less informed party to make inaccurate decisions when making a transaction, and the more informed party will also engage in acts that are detrimental to the other party when performing the transaction obligations. Information asymmetry manifests itself in three forms, namely, information time asymmetry, information volume asymmetry, and information disclosure level asymmetry. Asymmetric information is the result of parties receiving information, in which the disadvantage usually belongs to investors when receiving information to a lesser extent than information providers who are managers. The theory of asymmetric information is often used in studies to verify the influence of the factors of financial indicators shown on the financial statements in general and capital ownership structure in particular, in which relevant factors such as foreign ownership, state ownership, and ownership of organizations. This information may provide little or no information to external users and may be detrimental to users' information regarding capital ownership issues.

\subsection{Previous Studies}

Research on EMB has paid much attention to the companies, but the focus on the commercial banks is still modest. Iannotta, Nocera and Sironi (2007) studied 181 commercial banks of 15 European countries from 1999 to 2004. The results show that the degree of ownership concentration is positively related to the risks for these banks. Barry, Lepetit and Tarazi (2011) studied 249 commercial banks in Europe between 1999 and 2005. The study found that the ownership ratio of managers is negatively related to the level of bank risks. Alves (2012) studied 34 listed banks in Portugal from 2002 to 2007. The results show that the banks' financial management behaviors are affected by 
factors related to ownership structure. Shen (2016) looked at 16 listed banks in China from 2005 to 2014. Compared to previous studies using cumulative accounting variables to measure EMB, Shen (2016) used variables.

The dependent variable to measure the risk management behavior is adjusted risk related to provision expense ratio and bad debt provision ratio. The results show that the ownership ratio of a major shareholder is positively related, while the ownership ratio of a manager is negatively related to the EMB. Osemene, Adeyele and Adinnu (2018) studied the relationship between ownership structure and EMB at 14 Nigeria listed commercial banks over the 2011-2016 period. The author uses the self-determined provision for credit risk as a proxy for the performance of the credit risk management at banks. The regression results show that the ownership ratio of shareholders is a private enterprise; percentage of ownership of foreign shareholders; and the state's possession rate has the opposite effect on the management of behaviors. Sadjiarto, Monica and Budiarti (2019) studied capital structure and EMB at 45 listed commercial banks in the 2010-2017 period in Indonesia. The regression results show that the ownership structure has a significant impact on the management of private banking at banks, in which the increase in the percentage of shares owned by the State will have an impact to limit this behavior. However, the increase in the percentage of ownership in the remaining three forms of ownership facilitates the further enforcement of EMB. In addition, the variable of corporate governance mechanism and the capital adequacy variable have a positive effect on the dependent variable.

In Vietnam, EMB has been interested by a number of authors but only focused on enterprises (Huynh and Nguyen, 2019; Nguyen and Duong, 2020; Huynh, 2020). There has not been in-depth study of EMB at commercial banks except research by Tran and Nguyen (2018). However, that study used the OLS test method with 134 observations of 18 Commercial banks in Vietnam during the period of 12 years from 2005 to 2016. Tran and Nguyen (2018) were concerned about four typical variables of ownership structure. The results show that the foreign ownership ratio has a negative impact, the proportion of managerial ownership, the proportion of organizational ownership, and the degree of ownership concentration positively affect EMB. Recently, Tran and Tran (2020) examined the impact of factors related to financial indicators on earnings management of Vietnamese commercial banks. The authors considered a sample of 30 Vietnamese commercial banks during a 5-year period from 2015 to 2019. The results show that financial leverage and loan loss provision have a positive, while bank size and profitability are negatively associated with EMB.

In the context of the restructuring of Vietnam's banking system in recent years, Vietnam's legal regulations have been amended to allow changes in state and foreign ownership. Early 2020, Vietnam-EU Free Trade Agreement (EVFTA) approved by the National Assembly of Vietnam allowed EU credit institutions to raise foreign holdings to $49 \%$ of charter capital. The inheritance and expansion of research by Tran and Nguyen (2018) considers the relationship between ownership structure and EMB. This study will use six variables, adding two more variables such as state ownership rate and ownership ratio of members of the Board of directors. These two variables have been recently recognized by industry experts to affect the ownership structure of commercial banks. The study also increased the 15-year period from 2005 to 2019 due to the recent changes in Vietnam's legal structure of ownership in the banking sector. The study also increased the number of banks to 30 commercial banks out of 31 commercial banks in Vietnam. This helps to gain a broader view of EMB of Vietnamese commercial banks. Through that, it is to make improvements in the policies to control the EMB, thereby contributing to improving the quality of information on the financial statements of commercial banks in Vietnam.

\section{Research Methodology}

\subsection{Research Sample}

At the beginning of the first quarter of 2020, the author took a sample of 31 commercial banks in Vietnam and only one bank did not have enough financial statements data over many years, so this bank is not considered for the sample. Data is collected from the annual reports and financial statements of 30 Vietnamese commercial banks over 15 years, from 2005 to 2019, and ensures information on ownership structure and measurement indicators related to EMB. Accordingly, the data sample includes 415 observation samples of 30 commercial banks. The commercial banks are considered to ensure the information is adequate regarding the data of variables in the model and also ensure the sample size according to testing requirements.

\subsection{Research Models}

The article inherits the research model of Tran and Nguyen (2018) and combines the survey of some experts in the field of banking to see the conditions practice of Vietnamese commercial banks in recent years. Since then, the model identifies six independent variables, namely, the ratio of managerial ownership (MO), foreign ownership (FO), state ownership (SO), ownership of entities (IO), ownership of Board members (BO), and concentration of ownership (CO). For the dependent variable, the risk management behavior is measured by business risk adjusted by the provision for bad debt (LLR). Research model, specifically: 


$$
\begin{aligned}
\text { RISK_LLR }= & \alpha_{0}+\alpha_{1} \mathrm{MO}+\alpha_{2} \mathrm{IO}+\alpha_{3} \mathrm{SO}+\alpha_{4} \mathrm{FO}+\alpha_{5} \mathrm{BO} \\
& +\alpha_{6} \mathrm{CO}+\varepsilon
\end{aligned}
$$

The risk variable has a adjusted ratio of bad debt provision

$$
\text { RISK_LLR }=\frac{\text { LLR/ASSET }}{T-1}
$$

Inside:

$\operatorname{LLR}_{\mathrm{it}}$ : Allowance for credit losses / total loans of commercial banks (i) at year (t).

ASSET $_{t-1}$ : Total assets of the commercial bank (i) in the year $(\mathrm{t}-1)$

$\sigma_{\text {LLR/ASSET }_{\mathrm{t}-1}}:$ LLR / ASSETt-1 standard deviation for data

\begin{tabular}{|c|c|c|}
\hline Symbol & Name of variable & Measurement \\
\hline \multicolumn{3}{|c|}{ Dependent variable } \\
\hline $\begin{array}{l}\text { RISK_ } \\
\text { LLR }\end{array}$ & $\begin{array}{l}\text { Business risk is } \\
\text { adjusted to reserve } \\
\text { ratio for bad debts }\end{array}$ & $\frac{\text { LLR/ASSET }_{\mathrm{T}-1}}{\sigma_{\mathrm{LLR} / \mathrm{ASSET}_{\mathrm{T}-1}}}$ \\
\hline \multicolumn{3}{|c|}{ Independent variable } \\
\hline $\mathrm{CO}$ & $\begin{array}{l}\text { The degree } \\
\text { of ownership } \\
\text { concentration }\end{array}$ & $\begin{array}{l}\text { Percentage of } \\
\text { ownership held by } \\
\text { shareholders is } \\
\text { greater than } 5 \%\end{array}$ \\
\hline 10 & $\begin{array}{l}\text { Ownership rate of } \\
\text { organizations }\end{array}$ & \begin{tabular}{|l|} 
Percentage of \\
ownership held by \\
organizations
\end{tabular} \\
\hline MO & $\begin{array}{l}\text { Ownership rate of the } \\
\text { executive manager }\end{array}$ & $\begin{array}{l}\text { Percentage of } \\
\text { ownership held by the } \\
\text { executive manager }\end{array}$ \\
\hline SO & State ownership rate & $\begin{array}{l}\text { The percentage } \\
\text { owned by } \\
\text { shareholders is state }\end{array}$ \\
\hline $\mathrm{FO}$ & $\begin{array}{l}\text { Foreign ownership } \\
\text { ratio }\end{array}$ & \begin{tabular}{|l|} 
Percentage of \\
ownership held by \\
foreign investors
\end{tabular} \\
\hline $\mathrm{BO}$ & $\begin{array}{l}\text { Ownership ratio } \\
\text { of members of the } \\
\text { Board of directors }\end{array}$ & $\begin{array}{l}\text { Percentage of } \\
\text { ownership of } \\
\text { members of the Board } \\
\text { of directors }\end{array}$ \\
\hline
\end{tabular}
includes 15 years from 2005 to 2019

Table 1: Defining and measuring variables

\section{Research Results}

\subsection{Statistical Results}

According to the results of Table 2, the highest adjusted risk provision ratio (RISK_LLR) was 9.015 and the smallest was 0.026 , the average value was 1.472 with the standard deviation of 1.437 , equivalent to the average level. For the independent variables, the average level, in particular, is the foreign ownership rate (FO) is $12.12 \%$; The percentage of shares held by organizations (IO) is $22.19 \%$; state ownership (SO) is $27.28 \%$; the ownership rate of the manager (MO) is $7.02 \%$; the concentration of ownership (CO) is $42,213 \%$, and the ownership ratio of the Board members is $30.06 \%$. In addition, in general, the variables have unregulated standard deviations, except for the state ownership ratio (SO) of $34.83 \%$.

\subsection{Correlation Analysis Results}

According to Table 3 , the correlation coefficients between the independent variables are quite closely correlated and at the same time all correlation coefficients are less than 0.8 , so there is no multi-collinear phenomenon (Hair et al., 2006).

\subsection{Regression Analysis Results}

The results in Table 4 show that $\mathrm{R}^{2}$ is adjusted by 0.64 .21 and this parameter means that the independent variable explained $64.21 \%$ of the variation of the dependent variable. In general, this level of interpretation of the model is relatively good. The regression analysis results show that there are two independent variables with statistical significance (P-value is less than 0.05), the foreign ownership ratio (FO) and the concentration of ownership $(\mathrm{CO})$, respectively 0.037 and 0.018 . In particular, the proportion of foreign ownership (FO) has a negative effect, while the degree of ownership concentration (CO) has a positive impact on the management behavior of Vietnam's commercial banks. The results of this study are similar to those of Iannotta, Nocera and Sironi (2007); Alves (2012); Shen (2016). Interestingly, this study is different from Tran and Nguyen (2018). The study results have only two factors compared to four factors in Tran and Nguyen's (2018) study. This shows that Vietnam's regulations have affected the EMB of commercial banks over time. Accordingly, the specific model results: 
Table 2: Descriptive statistics results table

\begin{tabular}{|l|c|c|c|c|c|c|c|}
\hline Variables & RISK_LLR & FO & IO & SO & MO & CO & BO \\
\hline Mean & 1.472 & 12.116 & 22.185 & 27.281 & 7.016 & 42.213 & 30.061 \\
\hline Median & 1.118 & 11.725 & 21.842 & 12.623 & 3.811 & 36.518 & 28.714 \\
\hline Maximum & 9.015 & 29.214 & 60.364 & 96.810 & 31.127 & 98.915 & 49.520 \\
\hline Minimum & 0.026 & 0.000 & 0.421 & 0.000 & 0.000 & 0.000 & 10.118 \\
\hline $\begin{array}{l}\text { Standard } \\
\text { deviation }\end{array}$ & 1.437 & 11.106 & 15.118 & 34.825 & 8.948 & 26.681 & 25.451 \\
\hline $\begin{array}{l}\text { Number of } \\
\text { observations }\end{array}$ & 415 & 415 & 415 & 415 & 415 & 415 & 415 \\
\hline
\end{tabular}

Table 3: Matrix of correlation coefficients between variables in the model

\begin{tabular}{|l|c|c|c|c|c|c|}
\hline Variables & CO & FO & IO & MO & SO & BO \\
\hline CO & 1.000 & & & & & \\
\hline FO & 0.115 & 1.000 & & & & \\
\hline IO & -0.619 & -0.148 & 1.000 & & & \\
\hline MO & -0.421 & 0.428 & 0.224 & 1.000 & & \\
\hline SO & 0.651 & -0.458 & -0.671 & -0.502 & 1.000 & \\
\hline BO & 0.511 & 0.325 & 0.612 & 0.462 & 0.421 & 1.000 \\
\hline
\end{tabular}

Table 4: Regression results

\begin{tabular}{|l|c|c|}
\hline \multirow{2}{*}{ Variables } & \multicolumn{2}{|c|}{ RISK_LLR } \\
\cline { 2 - 3 } & $\boldsymbol{\alpha}$ & $\mathbf{P}$ value \\
\hline Constant & 0.085 & 0.000 \\
\hline IO & -0.021 & 0.271 \\
\hline CO & 0.037 & 0.000 \\
\hline FO & -0.018 & 0.000 \\
\hline MO & -0.084 & 0.124 \\
\hline SO & 0.015 & 0.168 \\
\hline BO & 0.034 & 0.115 \\
\hline Observations (N) & \multicolumn{2}{|c|}{0.6810} \\
\hline R squared & \multicolumn{2}{|c|}{0.642} \\
\hline $\begin{array}{l}\text { R squared } \\
\text { adjustment }\end{array}$ & \multicolumn{2}{|c|}{11.366} \\
\hline F-statistics & \multicolumn{2}{|c|}{0.0000} \\
\hline $\begin{array}{l}\text { Probability. } \\
\text { (F-statistics) }\end{array}$ &
\end{tabular}

\section{Conclusion and Policy Recommendations}

\subsection{Conclusion}

EMB, through the use of accounting procedures, takes advantage of the gaps in regulations and principles to implement accounting policies to bring specific benefits. This behavior has reduced the quality of accounting information as well as affected user decisions. Test results with 415 samples, including 30 commercial banks, over 15 years from 2005 to 2019. The results show that there are two factors affecting the quality management of commercial banks, in which the variable of foreign ownership ratio has the opposite effect, while the centralized ownership variable has the opposite effect. Therefore, in order to contribute to improving the quality of accounting information of Vietnam commercial banks, increasing the proportion of foreign equity and restricting ownership of ownership to a small number of shareholders is a matter that needs attention. This is a condition to ensure transparent financial information, increase trust for users in general, as well as for domestic and international investors. 


\subsection{Policy Recommendations}

It can be seen that the increase in foreign ownership ratio will have the effect of restricting the management of private credit behaviors; the higher level of concentration of ownership increases the behavior of private credit management in Vietnamese commercial banks. Therefore, in order to improve the quality of information, increasing the proportion of foreign ownership capital and limiting the ownership of ownership in a small number of shareholders in commercial banks is an issue that needs attention. The authors propose a number of policies for the State bank of Vietnam and Board of directors of commercial bank as well as investors.

On the side of State bank of Vietnam, it is necessary to amend the regulations in accordance with the need to improve the foreign ownership ratio in commercial banks. Currently, according to the Government's regulations (2007) on foreign investors buying shares of Vietnamese commercial banks, the total ownership ratio of foreign investors in a commercial bank is $30 \%$, of which the ownership of a share of a foreign investor other than a credit institution shall not exceed $5 \%$ and the shareholding percentage of a foreign credit institution shall not exceed $10 \%$ of the charter capital of a Vietnamese bank. Meanwhile, the recently-signed Vietnam-EU Free Trade Agreement (EVFTA), approved by the National Assembly of Vietnam, allowed EU credit institutions to raise foreign holdings to $49 \%$ of charter capital in two joint stock commercial banks of Vietnam (Vietnam Chamber of Commerce and Industry, 2020). In addition, State management agencies should also pay attention to expanding the foreign ownership ratio to increase resources in the economy through the relaxation of foreign ownership room in commercial banks. This also contributes to taking advantage of the management organizations of foreign managers in commercial banks to make the banking system ever more stable and sustainable.

For Board of directors of commercial banks, it is necessary to raise the awareness and responsibility of transparent information for users. In addition, in order to limit EMB, managers of commercial banks need to pay attention to attracting investment capital from foreign investors in the development strategy. In addition, managers also need to pay more attention to the percentage of ownership focused on certain shareholders. The concentration of ownership on a number of shareholders can lead to the concentration of rights on a small number of people, so financial mechanisms and policies are often more authoritarian. Not only that, the relevant financial information may also be affected by a small number of these people, so the information will be disproportionate to the user. Therefore, the management of commercial banks is interested in expanding the ownership ratio such as foreign ownership ratio, the ownership ratio of organizations will help commercial banks diversify their ownership structure to minimize micro EMB. This contributes to improving the quality of information to ensure trust for investors in particular and information users in general.

Particularly for investors, in order to have quality assurance information in making decisions, investors need to pay attention to commercial banks with foreign ownership, as well as consider and pay attention to centralized ownership rate of commercial banks. Accordingly, for commercial banks with a high percentage of foreign ownership, they often ensure more information transparency because the administration is clear so it is convenient for investors to make business decisions. Meanwhile, the high concentration rate of ownership in commercial banks will affect the quality of information in investors' business decisions because this concentration of information is sometimes disproportionate for users due to missing or incomplete information.

\section{References}

Akerlof, G. A. (1970). Quality Uncertainty and the Market Mechanism. The Quarterly Journal of Economics, 84(3), 488500. https://personal.utdallas.edu/ nina.baranchuk/Fin7310/ papers/Akerlof1970.pdf.

Akers, M. D., Giacomino, D. E., \& Bellovary, J. L. (2007). Earnings Management and Its Implications. The CPA Journal, 77(8), 64-68. https://epublications.marquette.edu/cgi/viewcontent. cgi? article $=1008 \&$ context $=$ account_fac.

Ali, S. M., Salleh, N. M., \& Hassan, M. S. (2008). Ownership structure and earnings management in Malaysian listed companies: the size effect. Asian Journal of Business and Accounting, 1(2), 89-116. https://www.academia.edu/25787931.

Alves, S. M .G. (2012). Ownership structure and Earning management: Evidence from Portugal. Australasian Accounting, Business and Finance Journal, 6(1), 57-74. https:// ro.uow.edu.au/cgi/viewcontent.cgi? referer=https://www. google.com.vn/\&httpsredir=1\&article=1278\&context=aabfj.

Barry, T. A., Lepetit, L., \& Tarazi, A. (2011). Ownership structure and risk in publicly held and privately owned banks. Journal of Banking \& Finance, 35, 1327-1340. https://hal.archivesouvertes.fr/hal-01098969/document.

Beneish, M. D. (2001). Earnings Management: A Perspective. Managerial Finance, 27(12), 3-17. https://www.emerald.com/ insight/content/doi/10.1108/03074350110767411/full/html.

Hair, J. J. F., Black, W. C., Babin, B. J., Anderson, R. E., \& Tatham, L. R. (2006). Multivariant Data Analysis. Hoboken, NJ: Pearson International. https:/www.scirp.org/ (S(lz5mqp453edsnp55rrgjct55).

Healy, P. M., \& Wahlen, J. M. (1999). A review of the earnings management literature and its implications for standard setting. Accounting Horizons, 13, 365-383. https://aaapubs.org/ doi/10.2308/acch.1999.13.4.365. 
Huynh, Q. L., \& Nguyen, V. N. (2019). The Effect of Prior Financial Performance on Organizational Reputation and Earnings Management. Journal of Asian Finance, Economics and Business, 6(4), 75-81. http:/doi:10.13106/jafeb.2019.vol6. no4.75

Huynh, Q. L A. (2020). Triple of Corporate Governance, Social Responsibility and Earnings Management. Journal of Asian Finance, Economics and Business, 7(3), 29-40. http:/ doi:10.13106/jafeb.2020.vol7.no3.29

Iannotta, G., Nocera, G., \& Sironi, A. (2007). Ownership structure, risk and performance in the European banking industry. Journal of Banking and Finance, 31(2007), 2127-2149. https:// hal-audencia.archives-ouvertes.fr/hal-00861806/document.

Jensen, M. C., \& Meckling, W. H. (1976). Theory of the Firm: Managerial Behavior, Agency Costs and Ownership Structure. Journal of Accounting and Economics, 3(4), 305-360. https:// uclafinance.typepad.com/main/files/jensen_76.pdf.

Nguyen, A. H., \& Duong, C. T. (2020). Provincial Governance Quality and Earnings Management: Empirical Evidence from Vietnam. Journal of Asian Finance, Economics and Business, 7(2), 43-52. http:/ doi:10.13106/jafeb.2020.vol7.no2.43

Osemene, O. F., Adeyele, J. S., \& Adinnu, P., (2018). The Impact of the Ownership Structure and Board Characteristics on the Earnings Management in Nigeria's Listed Deposit Money Banks. Economic Horizon, 20(3), 209-220. http://horizonti. ekfak.kg.ac.rs/sites/default/files/Casopis/2018_3/EH_2018_3_ en_3_JSA.pdf.

Potta, R. L., De-Silanes, F. L., \& Shleifer, A. (1999). Corporate Ownership around the World. Journal of Finance, 54(2), 471-517.https://onlinelibrary.wiley.com/doi/full/10.1111/00221082.00115 .

Rahman, M., Moniruzzaman, M., \& Sharif, J. (2013). Techniques, Motives and Controls of Earnings Management. International Journal of Information Technology and Business Management, 11(1), 22-34. .https://www.semanticscholar.org/paper/ Techniques\%2C-Motives-and-Controls-of-Earnings-Rahman Moniruzzaman/350d2fc2de705aae746c9460f102e79809333 $13 \mathrm{f}$ ?p2df

Ronen, J., \& Yaari, V. (2008). The Earnings Management Strategy to Meet or Beat Thresholds. Journal of Accounting, Taxation, and Law, 44(4), 1-41 https://www.sciencedirect.com/science/ article/abs/pii/S0020706311000239
Sadjiarto, A., Monica, C. C., \& Budiarti, W. R. (2019). Ownership Structure and Earnings Management in Indonesian Listed Banks. Journal of Economics and Business, 2(2), 261-272. https://www.asianinstituteofresearch.org/JEBarchives/.

Schipper, K. (1989). Commentary on earnings management. Accounting Horizons, 3(4), 91-102. http://www.sciepub.com/ reference/141020.

Shaikh, A. M., Iqbal, M. J., \& Shah, S. Z. A. (2012). Institutional Ownership and Discretionary Accruals: EMBirical Evidences from Pakistani Listed Non-Financial Companies. Information Management Business Review, 4(4), 217-222. https://ideas. repec.org/a/rnd/arimbr/v4y2012i4p217-222.html.

Shen, L. (2016). Research on Industry Competition, Ownership Structure and Earnings Management: EMBirical Analysis based on Listed Bank. International Journal of Smart Home, 10(3), 221-230. https://www.researchgate.net/publication/301727675.

Spence, M. (1973). Job Market Signaling. The Quarterly Journal of Economics, 87(3), 355-374. https://academic.oup.com/qje/ article-abstract/87/3/355/1909092?redirectedFrom=fulltext.

Tangjitprom, N. (2013). The Role of Corporate Governance in Reducing the Negative Effect of Earnings Management. International Journal of Economics and Finance, 5(3), 213-220. http://www.ccsenet.org/journal/index.php/ijef/article/ view/25164.

The Government of Vietnam. (2007). Decree No. 69/2007/ND-CP of the Government on foreign investors' purchase of shares of Vietnamese commercial banks, issued on May 24, 2007. Vietnam News. Retrieved April 16, 2020, from http://vanban.chinhphu. vn/portal/page/portal/chinhphu/hethongvanban?class_id=1\&_ page $=1 \&$ mode $=$ detail\&document_id $=23320$

Tran, T. Q., \& Nguyen, D. K. N. (2018). Testing the relationship between ownership structure and profit management behavior at Vietnamese joint stock commercial banks. Journal of Accounting and Auditing, 178, 35-40.

Tran, T. Q., \& Tran, N. A. T. (2020). Influence of financial indicators on earnings management behavior: evidence from Vietnamese commercial banks. Banks and Bank Systems, 15(2), 167-176. http://dx.doi.org/10.21511/bbs.15(2).2020.15.

Vietnam Chamber of Commerce and Industry. (2020). Free Trade Agreement between the Socialist Republic of Vietnam, and the European Union. Vietnam News. Retrieved April 16, 2020, from https://trade.ec.europa.eu/doclib/press/index.cfm?id=2041. 